\title{
The effects of storage temperature and position on embryonic mortality of ostrich (Struthio camelus) eggs
}

\author{
U. Sahan ${ }^{\#}$, A. Ipek and B. Yilmaz \\ Department of Animal Science, Faculty of Agriculture, University of Uludag, 16059, Gorukle, Bursa, Turkey
}

\begin{abstract}
The present study was carried out with the aim of determining the effects of storage temperature and storage position on embryonic mortalities in ostrich eggs. A total of 229 ostrich eggs was collected from two commercial ostrich farms. The effects of storage temperature on embryonic mortality differed. Embryonic deaths (totalled for early, medium and late incubation) were determined at respectively $28.6,32.0,42.9 \%$ in groups of eggs from stored immediately after collection for seven days at $16{ }^{\circ} \mathrm{C}, 21{ }^{\circ} \mathrm{C}$ and $25{ }^{\circ} \mathrm{C}$. Embryonic mortality was not affected by storing eggs for one week at $16{ }^{\circ} \mathrm{C}$ in either the vertical position (with the aircell at the top, or the aircell at the bottom) or the horizontal position. The percentage of embryonic mortalities was $25.8,26.7,24.1$ for the different storage positions, respectively. These results indicate that ostrich eggs must be stored at $21{ }^{\circ} \mathrm{C}$ or less after collection to maximise hatchability and that embryonic survival is not affected by storing position.
\end{abstract}

Keywords: Ostrich, pre-incubation storage conditions, incubation

"Corresponding author. E-mail: umran@uludag.edu.tr

\section{Introduction}

Egg storage conditions prior to incubation can influence hatchability and are thus of considerable concern to commercial hatchery enterprises (Butler, 1991). Environmental conditions including storage time, temperature, humidity, gaseous environment and orientation of the eggs influence ostrich egg hatchability (Meijerhof, 1992; Mellett, 1993). Ostrich eggs are normally stored for up to a week before being artificially incubated. At the start and end of the season, however, storage may be even longer in order to ensure that sufficient eggs are available (Deeming \& Ar, 1999). Storage conditions should be sufficiently cool to prevent embryonic development during this period. For most birds, the critical temperature for the initiation of embryonic development appears to be about $25-27^{\circ} \mathrm{C}$ (Drent, 1975). Optimum incubation conditions should be applied for the proper development of the ostrich embryo. One of the most important conditions is temperature. The absolute minumum temperature for blastoderm development in ostrich eggs is not known precisely. Van Schalkwyk et al. (1999) have shown that there is still some development at $20{ }^{\circ} \mathrm{C}$. However, the minimum temperature for ostrich embryonic development (the "physiological zero") is usually assumed to be $21{ }^{\circ} \mathrm{C}$ (Horbanczuk, 2002). On ostrich farms, storage temperatures may vary from $17{ }^{\circ} \mathrm{C}$ to $30{ }^{\circ} \mathrm{C}$, depending on storage facilities. Apart from storage time and temperature, the position of eggs during storage may affect hatchability. Traditionally, eggs are stored in the small-end-down position before incubation (Mayes \& Takeballi, 1984). However, very little research has been conducted on the effect of storage position on the hatchability of ostrich eggs. The present study was conducted to determine the effect of storage position and storage temperature conditions on embryonic mortalities in ostrich eggs.

\section{Material and Methods}

This research was carried out on two different commercial farms. On each farm, ostrich eggs were collected for usage as trial material. The nests of the ostriches were checked 2-3 times a day and eggs were transferred to a storage room. The initial egg weights were found to be similar for the two trials.

\section{Trial 1 (Farm A): Storage Temperature Conditions}

The eggs were collected and marked. Eggs were then allocated randomly to three treatments. Eggs were stored for seven days. Since the size of the commercial ostrich breeding flocks was small, the number of eggs collected daily was limited. Therefore, each treatment was replicated six times with 5-7 eggs constituting a replication, depending on the numbers of eggs available. A total of 105 eggs was used in this trial. 
Treatments were as follows;

- Stored at $16^{\circ} \mathrm{C}$ immediately after collection (Control)

- Stored at $21^{\circ} \mathrm{C}$ immediately after collection

- Stored at $25^{\circ} \mathrm{C}$ immediately after collection

Eggs were kept at $40 \%$ relative humidity during storage. After storage for seven days, the eggs were incubated in a Masalles 2600-I incubator for 38 days at a temperature of $36.5{ }^{\circ} \mathrm{C}$ and $30 \%$ relative humidity. The eggs were turned every hour through an angle of about $45^{\circ}$. On the $14^{\text {th }}$ day of incubation infertile eggs were identified by candling, and removed from the incubator. The eggs were candled again on the $38^{\text {th }}$ day of incubation. Those exhibiting embryonic mortality were identified, discarded and opened to determine the age of the embryo at death. Viable eggs were transferred to a hatcher (Masalles $1300-\mathrm{N}$ ) maintained at $36{ }^{\circ} \mathrm{C}$ and $40 \%$ relative humidity until hatching. Infertility and embryonic deaths were recorded individually and totalled for batches of eggs. Infertility was calculated as a percentage of eggs set and embryonic deaths as a percentage of fertile eggs within batches.

\section{Trial 2 (Farm B): Storage Position}

Eggs were stored for seven days at $16^{\circ} \mathrm{C}$ and $40 \%$ relative humidity before incubation. Each treatment was replicated eight times. The eggs were placed in trays, which were turned once each day through an angle of $90^{\circ}$. A total 124 eggs was used in Trial 2. Treatments were as follows;

- Long axis horizontal

- Vertical position with the aircell at the top

- Vertical position with the aircell at the bottom

Before storage, the position of the aircell was determined by candling the eggs with a 3 volt torch, and the position of the aircell was marked with a pencil. Incubation procedures and the recording of infertility and embryonic deaths were as described in Trial 1. Data were analyzed by analysis of variance according to a complete design, using Duncan's multiple range test to compare treatment means (Minitab, 1989).

\section{Results and Discussion}

The effect of storage temperature on hatchability is presented in Table 1. Embryonic mortality was affected $(\mathrm{P}<0.05)$ by storage conditions.

Table 1 Mean ( \pm s.e.) fertility and embryonic mortality percentages of egg stored at different temperatures

\begin{tabular}{lccc}
\hline & \multicolumn{3}{c}{ Storage temperatures } \\
\cline { 2 - 3 } Parameter & $16{ }^{\circ} \mathrm{C}$ & $21{ }^{\circ} \mathrm{C}$ & $25{ }^{\circ} \mathrm{C}$ \\
\hline Fertility (\%) & $70.0 \pm 2.3$ & $71.4 \pm 2.8$ & $70.0 \pm 2.2$ \\
Embryonic mortalities (\%) & $28.6 \pm 3.2^{\mathrm{a}}$ & $32.0 \pm 3.6^{\mathrm{a}}$ & $42.9 \pm 5.2^{\mathrm{b}}$ \\
(early, mid, late dead embryos) & & & \\
\hline a,b,c Row means with common superscripts do not differ $(\mathrm{P}<0.05)$ &
\end{tabular}

Embryonic mortality was higher in the group of eggs stored at $25{ }^{\circ} \mathrm{C}$ immediately after collection than in the other two groups $(\mathrm{P}<0.05)$. Acceptable hatching performance was found in ostrich eggs stored immediately after collection at $21^{\circ} \mathrm{C}$ or less for seven days. This corresponds with the observation of Deeming \& $\operatorname{Ar}$ (1999), who suggested that the hatchability of ostrich eggs stored at room temperature (mean $20{ }^{\circ} \mathrm{C}$ ) for up to seven days was not reduced by the length of storage. They also recommended that for best hatching, storage temperature should be lowered as storage time is extended. However, the functional effects of different storage conditions on the embryo and hatchability are not fully understood in ratite eggs (Meijerhof, 1992; Deeming, 1997).

Many researchers have reviewed the effects of storage time on the hatchability of ostrich eggs (Wilson et al. 1997; Ar \& Gefen, 1998; Badley, 1998; Nahm, 2001). Deeming (1996) found that for 12-14 days of storage, hatchability of fertile eggs was only $50 \%$, and thus associated with high early mortality. Wilson et al. (1997) found a similar decline in hatchability. The best hatchability was obtained for ostrich eggs stored at $15{ }^{\circ} \mathrm{C}$ for 4-6 days. However, Gonzalez et al. (1999) found that ostrich eggs could be stored at $18{ }^{\circ} \mathrm{C}$ for 
10 days without hatching being impaired. Similarly, Kocan (1993) stated that the prestoring of ostrich eggs for 10-12 days gave hatching results similar to those stored for five days or less.

The combined data suggest an interaction between storage temperature and storage time. Kirk et al. (1980) found that chicken eggs stored for two days hatched better when stored at $18{ }^{\circ} \mathrm{C}$ than at $15{ }^{\circ} \mathrm{C}$, whereas the opposite was true for eggs stored for eight days. However, long-term storage appears to be most successful at or near $12{ }^{\circ} \mathrm{C}$ (Funk \& Forward, 1960). Mayes \& Takeballi (1984) concluded that the shorter the storage period, the higher the storage temperature required for maximum hatchability. Deeming (1993), suggested that for ostrich eggs stored for up to seven days, a temperature of $16-18{ }^{\circ} \mathrm{C}$ is appropriate, while for eggs stored for longer than a week the temperature should be kept at approximately $13{ }^{\circ} \mathrm{C}$. Badley (1998) found that eggs stored at $21{ }^{\circ} \mathrm{C}$ for $13-18$ days had a very poor hatchability compared to eggs stored for less than four days. Laing (1992) suggested temperatures from 18 to $20{ }^{\circ} \mathrm{C}$, on condition that the storing time does not exceed four days. In addition, Horbanczuk (2000) determined that the temperature at which eggs are stored for a period not exceeding seven days may range from 12 to $18{ }^{\circ} \mathrm{C}$. The latter author also found that the hatchability of fertile eggs stored at $12{ }^{\circ} \mathrm{C}, 15{ }^{\circ} \mathrm{C}, 18{ }^{\circ} \mathrm{C}$ was similar and ranged from 78.9 to $80.7 \%$. Van Schalkwyk et al. (1999) showed that storage temperature was a key factor in determining embryonic viability and found that embryonic mortality was lower at a storage temperature at $17^{\circ} \mathrm{C}$ than at $25{ }^{\circ} \mathrm{C}$. This result is consistent with ours.

In addition, temperature during storage is directly related to albumen quality changes, which are related to these time and temperature dependent effects (Brake et al., 1993). Goodrum et al. (1989) reported that albumen $\mathrm{pH}$ increased rapidly when eggs were stored at high temperatures. The most important effect of albumen quality appears to be on early embryonic mortality (Brake et al., 1993).

In the wild, ostrich adults are capable of incubating up to 22 eggs per nest (Bertram, 1979). Oviposition in ostriches is approximately at two day intervals. The eggs laid early in a nest thus typically remain in the nest for two to three weeks before being incubated naturally (Bertram \& Burger, 1981). All eggs in a clutch hatch at the same time. The first eggs in the clutch have the highest quality albumen and retains its desirable physical properties for a longer period than the last eggs and is thus more resistant to high temperatures (Brake et al., 1994). The conditions of egg storage in the wild would be more harsh (exposed to the sun). Nevertheless, hatching success of eggs in the wild is considerably higher than that found with artificial incubation (Bertram \& Burger, 1981). For artificial incubation of ratite eggs, Brake et al. (1994) advocated the adjusting of storage time and conditions, and incubation conditions according to hen age, stage in laying season, albumen quality and the incidence of early embryonic mortality.

The mean hatchabilities of eggs stored in different positions are given in Table 2. The mean fertility percentages in this trial were unaffected $(\mathrm{P}>0.05)$ by egg position during storage. Embryonic mortalities were indepent $(\mathrm{P}>0.05)$ of storage position.

Table 2. Mean ( \pm s.e.) fertility and embryonic mortality percentages of egg stored in different positions

\begin{tabular}{lccc}
\hline & \multicolumn{3}{c}{ Egg storage position } \\
\cline { 2 - 4 } Parameter & 1 & 2 & 3 \\
\hline Fertility (\%) & $72.1 \pm 1.1$ & $73.2 \pm 1.3$ & $72.5 \pm 1.2$ \\
Embryonic mortalities (\%) & $25.8 \pm 2.9$ & $26.7 \pm 3.4$ & $24.1 \pm 2.8$ \\
(early, mid, late dead embryos) & & & \\
\hline
\end{tabular}

1 - Vertical position with the aircell at the top

2 - Vertical position with the aircell at the bottom

3 - Long axis horizontal

The position of chicken eggs during storage has been reviewed extensively. The small-end-down position was suggested to help maintaining the aircell in its original position and provides the highest rate of survival of embryos. However, it was reported that hatchability was improved when chicken eggs were stored with their pointed-ends up (Proudfoot, 1969; Mayes \& Takeballi, 1984; Butler, 1991; İpek et al., 1997). Mayes \& Takebelli (1984) suggested that the small-end-up position may be beneficial because it keeps the yolk near the centre of the albumen and thus gives the dormant embryo greater protection from dehydration and adhesion to the inner shell membrane. However, Van Schalkwyk et al. (1999) found that egg position (either aircell at the top, aircell at the bottom or the egg in a horizontal position) did not affect 
embryonic mortality of ostrich eggs stored for up to six days. In addition, eggs are occasionally stored for longer than one week on commercial ostrich farms, depending on the number of eggs incubated and the hatchery infrastructure. Hatchability seems to be unaffected by the position they were stored before incubation. This agrees with our results.

\section{Conclusions}

The present study suggests that ostrich eggs can be stored after collection and before incubation for up to seven days at $16^{\circ} \mathrm{C}$ without affecting hatchability irrespective of the position of the eggs. Eggs should be stored after collection at temperatures of $21{ }^{\circ} \mathrm{C}$ or less to minimise embryonic mortality. Further research with ratite eggs is required to clarify the effects of egg storage for long periods on their hatchability.

\section{References}

Ar, A. \& Gefen, E., 1998. Further improving hatchability in artificial incubation of ostrich eggs. Proc. Conf.: Improving our understanding of Ratites in a competitive world. Oudtshoorn, South Africa, September 21-25, 1998. pp.141-147.

Badley, A., 1998. Boosting ostrich productivity through better egg hatchability. A report for the Rural Industries Research and Development Corporation, No: 98/17.

Bertram, B.C.R., 1979. Breeding system and strategies of ostriches. In: Proc. $17^{\text {th }}$ Int. Orn. Cong., Symp. of Altruism, Berlin, Germany. pp. 890-894.

Bertram, B.C.R. \& Burger, A.E., 1981. Aspects of incubation in ostriches. Ostrich 52, 36-43.

Brake, J., Walsh, T.J. \& Vick, S.V., 1993. Relationship of egg storage time, storage conditions, flock age, eggshell and albumen characteristics, incubation conditions and machine capacity to broiler hatchability. Zootech. Int. 16, 1, 30-41.

Brake, J., Davis, G.S., Rosseland, B. \& Delfel, S., 1994. Further refinements in the incubation and hatching of ratites. The Ostrich News (USA) 7, 65, pp. 54-59.

Butler, D.E., 1991. Egg handling and storage at the farm and hatchery. In: Avian incubation. Ed. Tullet, S.G., Butterworth-Heinemann, London, UK. pp. 195-203.

Deeming, D.C., 1993. The incubation requirements of ostrich (Struthio camelus) eggs and embryos. In: Ostrich odyssey: Proc. of the meeting of the Australian Ostrich Association Inc. (Vic), 217. Ed. Bryden, D.I., Post Graduate Committee in Veterinary Science, University of Sydney. pp. 1-66.

Deeming, D.C., 1996. Production, fertility and hatchability of ostrich (Struthio camelus) eggs on a farm in the United Kingdom. Anim. Sci. 63, 329-336.

Deeming, D.C., 1997. Ratite egg incubation - a practical guide. Ratite Conf., Buckinghamshire, UK.

Deeming, D.C. \& Ar, A., 1999. Factors affecting the success of commercial incubation. In: The ostrich: biology, production and healthy. Ed. Deeming, D.C., CABI Publishing, University of Manchester. pp. 159-190.

Drent, R.H., 1975. Incubation. In: Avian biology. Eds. Farner, D.S. \& King, J.R., Academic Press, London. Vol. 5, pp. 333-420.

Funk, E.M. \& Forward, J.F., 1960. Effect of holding temperature on hatchability of chicken eggs. Missouri Agric. Exper. Sta. Bull. p. 732.

Goodrum, J.W., Britton, W.M. \& Davis, J.B., 1989. Effect of storage conditions on albumen pH and subsequent hard-cooked eggs peelability and albumen shear strength. Poult. Sci. 68, 1226-1231.

Gonzalez, A., Satterlee, D.G., Moharer, F. \& Cadd, G.G., 1999. Factors affecting ostrich egg hatchability. Poult. Sci. 78, 1257-1262.

Horbanczuk, J.O., 2000. Doskonalenie technologii sztucznych legow strusia afrykanskiego (Struthio camelus) z uwzglednieniem aspektow biologicznych. Rozprawa habilitacyjna. In Polish, summary in English. Prace i Materialy Zootechniczne, Zeszyt Specjalny 10.

Horbanczuk, J.O., 2002. Incubation and hatching. In: The Ostrich. ISBN 83-916046-5-9, Warsaw, pp. 85117.

Ipek, A., Şahan, Ü. \& Yıldırım, Z., 1997. Etlik ana damızlık yumurtalarında depolama süresi ve pozisyonlarının kuluçka özelliklerine etkileri. Uludağ Üniv. Zir. Fak. Derg. 13, 89-98.

Kirk, S. Emmans, G., McDonald, R. \& Arnot, D., 1980. Factors affecting the hatchability of eggs from broiler breeders. Br. Poult. Sci. 21, 37-53. 
Kocan, A., 1993. Weight loss determinations to minimize early chicks deaths in artificially hatched ostrich. The ostrich news (USA). Annual Sixth Edition, 184-185.

Laing, R., 1992. Incubation techniques. In: Ostrich workshop for veterinarians. Zimbabwe University, Veterinary Faculty, Harare, April 11-12, pp. 51-60.

Mayes, F.J. \& Takeballi, M.A., 1984. Storage of the eggs of the fowl (Gallus domesticus) before incubation: a review. Wld Poult. Sci. J. 40, 131-140.

Meijerhof, R., 1992. Pre-incubation holding of hatching eggs. Wld Poult. Sci. J. 48, 57-68.

Mellet, F.D., 1993. Ostrich production and products. In: Livestock production systems; Principles and practice. Eds. Maree, C. \& Casey, N.H., Agri Development Foundation, Pretoria. pp.187-194.

Minitab, 1989. Minitab Release 9.2, Manuel Reference, April, Minitab Inc.

Nahm, K.H., 2001. Effect of storage length and weight loss during incubation on the hatchability of ostrich eggs (Struthio camelus). Poult. Sci. 80, 1667-1670.

Proudfoot, F.G., 1969. Effect of packing orientation, daily positional change and vibration on hatchability of chicken eggs stored up to four weeks. Can. J. Anim. Sci. 49,29.

Van Schalkwyk, S.J., Brand, Z., Cloete, S.W.P. \& Brown, C.R., 1999. Effects of time of egg collection and pre-incubation treatment on blastoderm development and embryonic mortality in ostrich embryos. S. Afr. J. Anim Sci. 29, 154-163.

Wilson, H.R., Eldred, A.R. \& Wilcox, C.J., 1997. Storage time and ostrich egg hatchability. J. Appl. Poult. Res. 6, 216-220. 